\title{
Dopaminergic Modulation of Forced Running Performance in Adolescent Rats: Role of Striatal D1 and Extra-striatal D2 Dopamine Receptors
}

\author{
Angel Toval ${ }^{1,2}$ - Daniel Garrigos ${ }^{1,2}$ - Yevheniy Kutsenko ${ }^{1,2} \cdot$ Miroljub Popović $^{1,2}$ - Bruno Ribeiro Do-Couto ${ }^{3}$. \\ Nicanor Morales-Delgado ${ }^{1,2,4} \cdot$ Kuei Y. Tseng ${ }^{5}$. José Luis Ferran ${ }^{1,2}$ (D)
}

Received: 6 October 2020 / Accepted: 4 December 2020 / Published online: 4 January 2021

(C) The Author(s) 2021

\begin{abstract}
Improving exercise capacity during adolescence impacts positively on cognitive and motor functions. However, the neural mechanisms contributing to enhance physical performance during this sensitive period remain poorly understood. Such knowledge could help to optimize exercise programs and promote a healthy physical and cognitive development in youth athletes. The central dopamine system is of great interest because of its role in regulating motor behavior through the activation of D1 and D2 receptors. Thus, the aim of the present study is to determine whether D1 or D2 receptor signaling contributes to modulate the exercise capacity during adolescence and if this modulation takes place through the striatum. To test this, we used a rodent model of forced running wheel that we implemented recently to assess the exercise capacity. Briefly, rats were exposed to an 8-day period of habituation in the running wheel before assessing their locomotor performance in response to an incremental exercise test, in which the speed was gradually increased until exhaustion. We found that systemic administration of D1-like (SCH23390) and/or D2-like (raclopride) receptor antagonists prior to the incremental test reduced the duration of forced running in a dose-dependent manner. Similarly, locomotor activity in the open field was decreased by the dopamine antagonists. Interestingly, this was not the case following intrastriatal infusion of an effective dose of SCH23390, which decreased motor performance during the incremental test without disrupting the behavioral response in the open field. Surprisingly, intrastriatal delivery of raclopride failed to impact the duration of forced running. Altogether, these results indicate that the level of locomotor response to incremental loads of forced running in adolescent rats is dopamine dependent and mechanistically linked to the activation of striatal D1 and extrastriatal D2 receptors.
\end{abstract}

Keywords Habituation $\cdot$ Endurance $\cdot$ Dopaminergic system $\cdot$ Exercise capacity $\cdot$ Motor learning $\cdot$ Central fatigue

José Luis Ferran

jlferran@um.es

1 Department of Human Anatomy and Psychobiology, Faculty of Medicine, University of Murcia, Murcia, Spain

2 Institute of Biomedical Research of Murcia - IMIB, Virgen de la Arrixaca University Hospital, University of Murcia, Murcia, Spain

3 Department of Human Anatomy and Psychobiology, Faculty of Psychology, University of Murcia, Murcia, Spain

4 Department of Histology and Anatomy, Faculty of Medicine, University Miguel Hernández, Sant Joan d'Alacant, Spain

5 Department of Anatomy and Cell Biology, University of Illinois at Chicago, Chicago, IL, USA

\section{Introduction}

A healthier life expectancy is associated with physical activity $[1,2]$, yet the biological mechanisms underlying such an effect remain poorly understood. Physical activity is a powerful enhancer of brain plasticity and positively impacts a broad set of cognitive and motor functions [3-6]. In fact, the maximal amount of physical activity an individual can perform (defined as exercise capacity) [7] is a good predictor of health status and physical fitness, and it is commonly used for individualized exercise programs [8-10]. Of particular interest is the adolescent period, which is characterized by key behavioral and biological changes in physical development and brain circuit maturation [11-17]. In order to enhance the potential and development of adolescent athletes, the different 
stages of exercise programs (e.g., physical literacy, motor coordination skills) need to be adapted to the biological maturity of this sensitive period $[11,12]$. Thus, understanding the underlying neural processes that contribute to the enhancement of physical performance during adolescence will allow to act upon such precise neurobiological mechanism to optimize training programs in youth athletes.

Among the different neural processes contributing to brain maturation during adolescence is the central dopamine system [13, 14, 18], which also plays a crucial role in modulating a wide variety of cognitive and motor behavior including locomotor activity, learning, and memory [19-23]. At the cellular level, dopamine exerts its excitatory and inhibitory actions on targeted neurons depending on which receptor is being activated. There are five different types of dopamine receptors, which can be grouped into two major families: D1-like (constituted by D1R and D5R) and D2-like (constituted by D2R, D3R, and D4R). D1-like receptor family has an excitatory effect, whereas D2-like receptors have an inhibitory effect [24-26]. Among the main targets of the dopamine system are the corticostriatal circuits, which are composed of striatal output neurons containing D1 (direct pathway) and D2 (indirect pathway) receptors. Direct and indirect pathways are part of the cortico-basal ganglia-thalamocortical loop. Direct pathway projects from striatum to substantia nigra pars reticulata ( $\mathrm{SNr}$ ) and the internal portion of globus pallidus and facilitates initiation and execution of movement. Indirect pathway sends their primary striatal projections to the external portion of globus pallidus (GP) leading to inhibition of movement [20, 22, 23]. Pharmacological manipulation of dopamine receptors has shown effects on spontaneous motor activity and voluntary running [20, 27-34]. Moreover, increments in dopamine content and release have been observed in response to physical activity [3,35-38], and genetic and pharmacological studies have suggested that a reduction in dopamine function could limit the activation of motor circuits and negatively impact the exercise capacity [3, 39-41].

The aim of the present study is to determine whether the dopamine system modulates exercise capacity during adolescence using a rodent model of forced running wheel we recently implemented. Briefly, rats were exposed to an 8day period of habituation in the running wheel before assessing their locomotor performance in response to an incremental load of forced running [42, 43]. Both systemic and striatal administration of dopamine D1 (SCH23390) and D2 (raclopride) receptor antagonists were delivered 15-30 min prior to the onset of the incremental test, and changes in the level of locomotor performance were compared.

\section{Methods}

All the experimental procedures were approved by the Ethical Committee for Animal Research (CEEA) of the University of Murcia according to the Spanish regulation on the use of animals for scientific purposes (Royal Degree 53/2013, Law 32/ 2007) and European Union directives (86/609/EEC).

\section{Animals}

Adolescent male Sprague-Dawley rats (Laboratory Animal Facilities at the University of Murcia) aged P32-50 days were group housed ( 3 rats per cage) and randomly assigned to the different experimental groups. The randomization schedule was generated by using the website www.randomizer.org. Temperature and relative humidity were kept at $21-23{ }^{\circ} \mathrm{C}$ and $55 \pm 5 \%$. Chow food and water were provided ad libitum. The light cycle was kept in a 12:12-h light/dark (dark period from $8 \mathrm{AM}$ to $8 \mathrm{PM}$ ), and all the procedures were performed during the dark phase. All the rats were handled daily for 1 min during 5 days before the beginning of the habituation protocol to get familiarized with the researcher and the experimental conditions.

Rats subjected to stereotaxic surgery (at P41/42) were individually housed after surgery and during the exercise habituation protocol.

\section{Exercise Habituation and Incremental Test}

An 8-day exercise habituation protocol was implemented using a forced running wheel system (Lafayette-Campden, model 8085 A). Speed and time of running were progressively increased throughout the sessions of the protocol, from 5 at $0 \mathrm{~m} / \mathrm{min}$ the first day to $30 \mathrm{~min}$ running at $9 \mathrm{~m} / \mathrm{min}$ the last day, as described in Toval et al. $(2017,2020)$ [42, 43]. Nonhabituated rats remained in locked wheels, without any exercise stimulus, for the same time as the habituated groups.

Twenty-four hours after the last session of the habituation protocol, motor performance was evaluated by an incremental exercise test in all the animals. During the test, running speed was gradually increased $0.5 \mathrm{~m} / \mathrm{min}$ every minute from a starting speed of $5 \mathrm{~m} / \mathrm{min}$ (Fig. $1 \mathrm{~b}$, modified from Toval et al. $(2017,2020)[42,43])$. The test was concluded when the rat was unable to maintain a regular running path (e.g., crawling, jumping, or rolling inside the wheel) for $20 \mathrm{~s}$ in a row. The first 5 min were considered as warm-up phase, since some rats show transient irregular running paths at the beginning of the test. Thus, the mentioned criteria to stop the test were applied after these first $5 \mathrm{~min}$. The decision of concluding the test for every rat was achieved through consensus of two experimented researchers. 

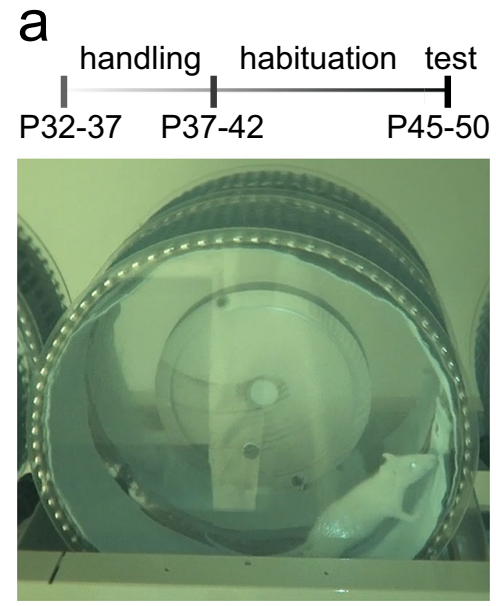

b

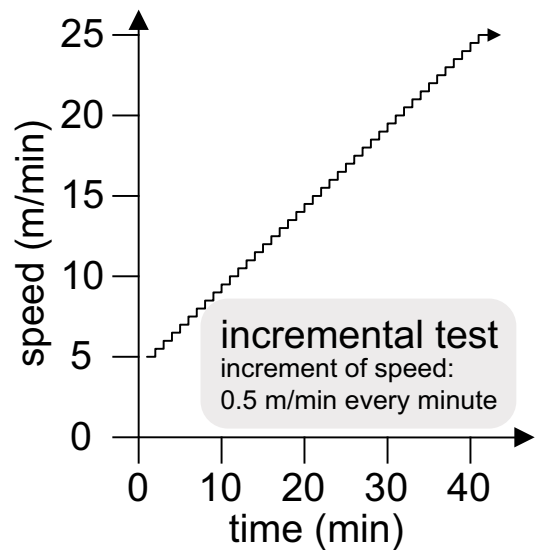

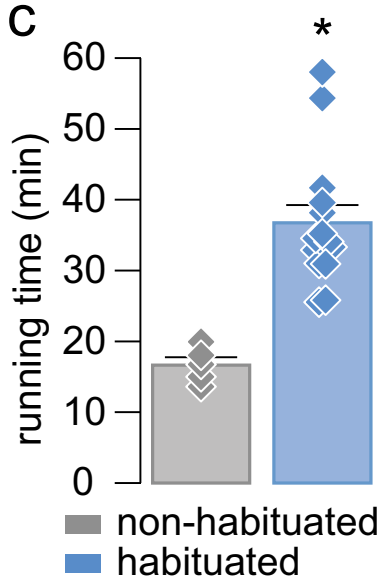

Fig. 1 Effects of habituation on the locomotor response during an incremental exercise test. (a) Timeline of the experiments and picture of an adolescent rat running in the forced wheel during the dark period. (b) Speed variation ( $y$-axis) along time ( $x$-axis) during the incremental exercise test. (c) Average of the total running time spent during the

\section{Drug Administration}

To evaluate whether the dopaminergic system plays a role in mediating the motor performance, dopamine receptors were pharmacologically blocked during the incremental test by systemic and intrastriatal administration of the dopamine D1 receptor antagonist SCH23390 (Hello Bio, HB1643) and the D2 receptor antagonist raclopride (Sigma, 98185-20-7). For systemic administration, drugs were diluted in $\mathrm{NaCl}, 0.9 \%$, and injected intraperitoneally (i.p.) in a volume of $0.5 \mathrm{ml}$. All systemic injections were applied $20 \mathrm{~min}$ before the incremental test. For intrastriatal administration, drugs were diluted in artificial cerebrospinal fluid (aCSF) composed of (in $\mathrm{mM}$ ) $122.5 \mathrm{NaCl}, 3.5 \mathrm{KCl}, 25 \mathrm{NaHCO}_{3}, 1 \mathrm{NaH}_{2} \mathrm{PO}_{4}, 2.5 \mathrm{CaCl}_{2}$, $1 \mathrm{MgCl}_{2}, 20$ glucose, and 1 ascorbic acid (pH: 7.4, 295$305 \mathrm{mOsm}$ ). All micro-infusions were performed bilaterally with a volume of $1 \mu \mathrm{L}$ per hemisphere at a rate of $0.5 \mu \mathrm{L} / \mathrm{min}$ using infusion cannulas (Plastics One, C315IA/SPC). After 2 min of infusion, an additional $1.5 \mathrm{~min}$ were given until the infusion cannula is removed, for a complete spreading of the drug. All intrastriatal infusions were applied 15-30 min before the incremental test.

\section{Experimental Design}

First, to assess the effects of habituation on locomotor performance, non-habituated and habituated rats were subjected to the incremental exercise test after systemic administration of vehicle $(\mathrm{NaCl} 0.9 \%$, i.p.).

Next, we aimed to find out the role of dopamine receptors in mediating the locomotor performance. For that purpose, D1-like receptors were selectively blocked by injecting $\mathrm{SCH} 23390$ (0.1 and $0.2 \mathrm{mg} / \mathrm{kg}$, i.p.) (Fig. 2a), and D2-like incremental exercise test comparing non-habituated (gray bar) and habituated (blue bar) rats injected with vehicle $(\mathrm{NaCl}, 0.9 \%$, i.p.). Data: nonhabituated: $16.65 \pm 1.11 \mathrm{~min}(n=5)$, and habituated: $36.75 \pm 2.52 \mathrm{~min}$ $(n=14) . t_{17}=4.6, * p<0.001$, unpaired $t$ test. Diamonds represent individual values

receptors were selectively blocked by injecting raclopride $(0.5$ and $1 \mathrm{mg} / \mathrm{kg}$, i.p.) (Fig. $2 \mathrm{~b})$ before the incremental test. These doses have been previously shown to induce effects on motor behaviors $[36,44]$. After that, we injected a combination of SCH23390 $(0.1 \mathrm{mg} / \mathrm{kg}$, i.p.) plus raclopride $(0.5 \mathrm{mg} / \mathrm{kg}$, i.p.) given together using the lowest effective dose when given alone (Fig. 2c). The running time spent during the test was compared with habituated rats injected with vehicle $(\mathrm{NaCl}$ $0.9 \%$, i.p.) (Fig. 2).

Finally, in order to determine whether the observed role of the dopaminergic system in motor performance was mediated by striatal neurons, intracerebral cannulas were implanted in the dorsal striatum (at $\mathrm{P} 41 / \mathrm{P} 42$ ) with the aim to specifically block striatal dopamine receptors. One week after the implantation of the cannula, rats were exposed to the habituation protocol, and, prior the incremental test, striatal D1 and D2 dopamine receptors were blocked by local administration of SCH23390 (D1 antagonist, $10 \mu \mathrm{M}$ and $100 \mu \mathrm{M}$ ) or raclopride (D2 antagonist, at $20 \mu \mathrm{M}, 200 \mu \mathrm{M}$, and $5 \mathrm{mM}$ ) (Fig. 3a, b). These doses have been previously shown to induce changes in the local field potential (LFP) activity of the cortex [45].

Furthermore, we assessed whether the observed effect of the dopamine system during forced running was also affecting ambulatory locomotor activity, evaluated by an open field test, as described below (Fig. 2d, 3c).

\section{Intrastriatal Implantation of Guide Cannulas}

Stereotaxic surgery was conducted under inhalation of isoflurane anesthesia (5\% for induction and 2-3\% for maintenance with $\mathrm{O}_{2}$ flow at $0.8 \mathrm{~L} / \mathrm{min}$ ). Rats were injected with a non-steroidal anti-inflammatory drug (meloxicam, s.c. $1.5 \mathrm{mg} / \mathrm{kg}$ ), with an antibiotic (enrofloxacin, i.m. $10 \mathrm{mg} / \mathrm{kg}$ ) 


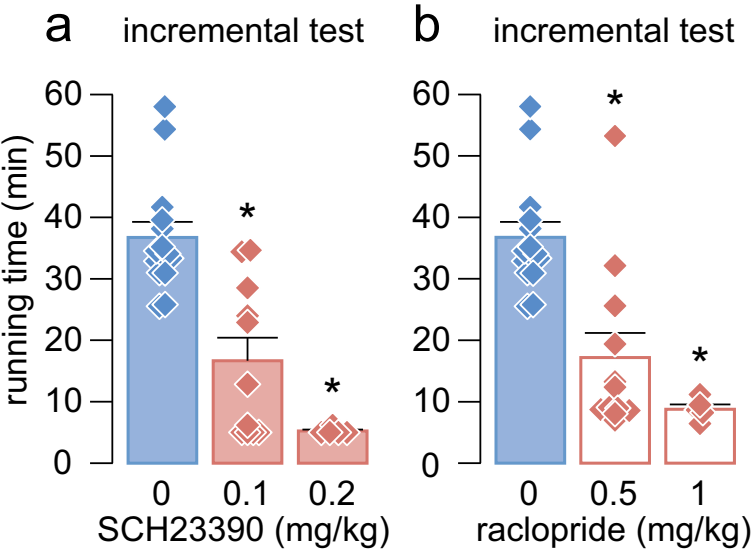

Fig. 2 Systemic blockade of D1 and D2 receptors during the incremental exercise test and open field. (a) Mean running time during the incremental test after systemic (i.p.) injection of the D1 antagonist SCH23390 (0.1 and $0.2 \mathrm{mg} / \mathrm{kg}$ ). Data: SCH23390: $0 \mathrm{mg} / \mathrm{kg}: 36.75 \pm 2.52 \mathrm{~min}(n=14$, blue bar), $0.1 \mathrm{mg} / \mathrm{kg}: 16.67 \pm 3.74 \mathrm{~min}(n=11$, red bar), and $0.2 \mathrm{mg} / \mathrm{kg}: 5.23 \pm$ $0.23 \mathrm{~min},\left(n=5\right.$, red bar). ${ }^{*} p<0.0001 \mathrm{vs} 0 \mathrm{mg} / \mathrm{kg}$, Tukey post hoc test after significant one-way ANOVA, $F_{2,27}=23.2, p<0.0001$. (b) Mean running time during the incremental test after systemic (i.p.) injection of the D2 antagonist raclopride $(0.5$ and $1 \mathrm{mg} / \mathrm{kg})$. Data: $0 \mathrm{mg} / \mathrm{kg}$ : $36.75 \pm 2.52 \mathrm{~min}(n=14$, blue bar), $0.5 \mathrm{mg} / \mathrm{kg}: 17.19 \pm 3.99 \min (n=12$, white bar), and $1 \mathrm{mg} / \mathrm{kg}: 8.78 \pm 0.78 \min (n=5$, white bar). $* p<0.001$ vs $0 \mathrm{mg} / \mathrm{kg}$, Tukey post hoc test after significant one-way ANOVA, $F_{2,28}=$ 17, $p<0.0001$. (c) Mean running time during the incremental test after

and with a local anesthetic (bupivacaine mixed with epinephrine, s.c. local, $1 \mathrm{mg} / \mathrm{kg}$; epinephrine 1:100000). Twenty-four hours after the surgery, the rats were given another injection of
C incremental test d open field test
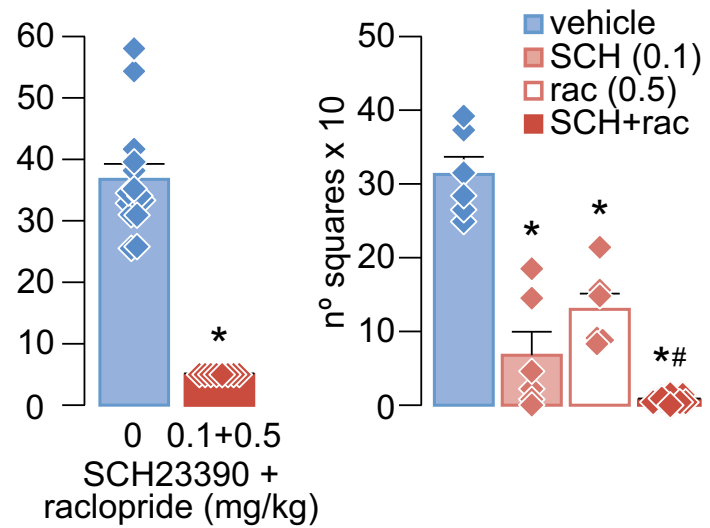

systemic (i.p.) injection of $\mathrm{SCH} 23390(0.1 \mathrm{mg} / \mathrm{kg})$ plus raclopride $(0.5 \mathrm{mg} / \mathrm{kg})$. Data: $0 \mathrm{mg} / \mathrm{kg}: 36.75 \pm 2.52 \mathrm{~min}(n=14$, blue bar $)$ and SCH23390 + raclopride: $5 \pm 0 \min (n=8$, red bar $) . t_{20}=9.4$, $* p<0.0001$, unpaired $t$ test. (d) Locomotor activity during an open field test, comparing the effects of systemic (i.p.) injections of vehicle (blue bar), $\mathrm{SCH} 23390(0.1 \mathrm{mg} / \mathrm{kg}$, light red bar $)$, raclopride $(0.5 \mathrm{mg} / \mathrm{kg}$, white bar), and SCH23390 $(0.1 \mathrm{mg} / \mathrm{kg})$ plus raclopride $(0.5 \mathrm{mg} / \mathrm{kg}$, dark red bar). Data: vehicle: $313 \pm 23.86(n=6), \mathrm{SCH} 23390: 67.67 \pm 31.85(n=$ 6), and raclopride: $130 \pm 21.25(n=6), \mathrm{SCH} 23390+$ raclopride: $7.14 \pm$ $1.95(n=7) . * p<0.0001$ vs vehicle, $\# p=0.0027$ vs raclopride, Tukey post hoc test after significant one-way ANOVA, $F_{3,21}=37.6$, $p<0.0001$. Diamonds represent individual values

meloxicam (s.c. $1.5 \mathrm{mg} / \mathrm{kg}$ ). These treatments were meant to achieve analgesia and improve animal welfare after surgery. Guide cannulas (Plastics One, C315GA/SPC, $8 \mathrm{~mm}$ ) were

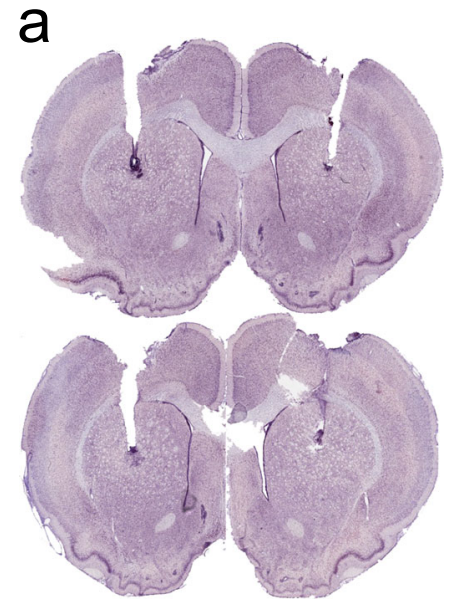

b

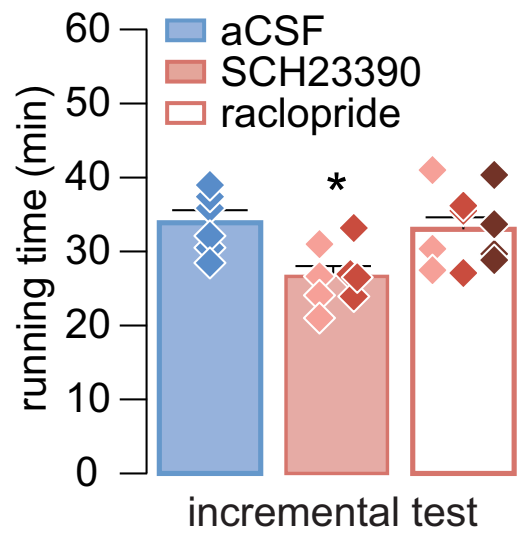

C

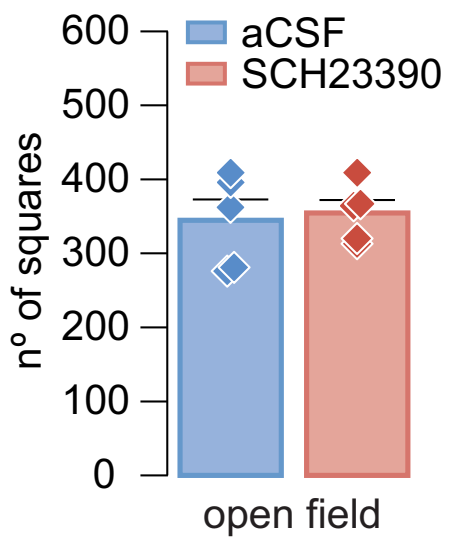

Fig. 3 Intrastriatal blockade of D1 and D2 receptors during the incremental exercise test and open field. (a) Examples of Nissl-stained coronal sections showing the site of injection. The image above shows an example of a rat injected with raclopride and the image below a rat injected with SCH23390. (b) Mean running time during the incremental exercise test after intrastriatal administration of aCSF (blue bar), SCH23390 (red bar, $10 \mu \mathrm{M}, \diamond$ and $100 \mu \mathrm{M}, \diamond$ ), or raclopride (white bar, $20 \mu \mathrm{M}, \diamond 200 \mu \mathrm{M}, \diamond$ and $5 \mathrm{mM}, \diamond$ ). Data from the different concentrations were pooled for treatment comparison. Data: aCSF:
$33.87 \pm 1.7 \mathrm{~min}(n=6), \mathrm{SCH} 23390,10$ and $100 \mu \mathrm{M}: 26.64 \pm 1.39 \mathrm{~min}$ $(n=8)$, and raclopride, $20 \mu \mathrm{M}, 200 \mu \mathrm{M}$, and $5 \mathrm{mM}(n=10): 33.01 \pm$ 1.62. ${ }^{*} p<0.02$ vs aCSF, Tukey post-hoc test after significant one-way ANOVA, $F_{2,21}=5.9, p<0.01$. Diamonds represent individual values. (c) Locomotor activity during an open field test, comparing the effects of intrastriatal administration (i.s.) of aCSF and SCH23390 $(100 \mu \mathrm{M})$. Data: aCSF (i.s.): $344.8 \pm 28.14$ ( $n=5$, blue bar) and SCH23390 (i.s.): $354.6 \pm 17.51$ ( $n=5$, red bar). $t_{8}=0.3, p=0.775$, unpaired $t$ test 
implanted bilaterally into the dorsal striatum at the following coordinates: anteroposterior (AP), $-0.7 \mathrm{~mm}$; lateral (L), + $3.0 \mathrm{~mm}$; and dorso-ventral (V), $-3.6 \mathrm{~mm}$ (Paxinos and Watson, 2007 [46]) and protected with dummy cannulas (Plastics One, C315DC/SPC, $8 \mathrm{~mm}$, without projection). After 1 week of post-operative recovery, with daily handling, rats started the habituation protocol at $\mathrm{P} 49$.

The day before the incremental test, the dummy cannula was replaced with a longer one (Plastics One, C315IA/SPC9) that protruded $0.5 \mathrm{~mm}$ beyond the tip of the guide cannula to reduce possible damage caused by the infusion cannula and to facilitate drug spreading. After the experiment, rats were sacrificed, and cannula placement was confirmed by Nisslstained coronal sections (Fig. 3a). Rats with off-target cannulations were excluded from the study.

\section{Open Field Test}

The open field test was performed in a white plywood box $(100 \times 100 \times 40 \mathrm{~cm})$ under $4 \mathrm{~lx}$ intensity and recorded using a video camera. The floor was divided into 25 squares $(20 \times 20$ $\mathrm{cm})$. All rats were started the test at the same corner of the box 20 min after systemic (i.p.) administration of SCH23390 $(0.1 \mathrm{mg} / \mathrm{kg})$, raclopride $(0.5 \mathrm{mg} / \mathrm{kg})$, a combination of $\mathrm{SCH} 23390(0.1 \mathrm{mg} / \mathrm{kg})$ plus raclopride $(0.5 \mathrm{mg} / \mathrm{kg}$, ) or vehicle $(\mathrm{NaCl} 0.9 \%)$ (Fig. 2d) and $15 \mathrm{~min}$ after intrastriatal infusion of SCH23390 (100 $\mu \mathrm{M}$, diluted in aCSF) and vehicle (aCSF) (Fig. 3c). For the open field test, the lowest effective dose during the incremental test in the forced wheel was used. The behavior of the animals was monitored for $15 \mathrm{~min}$. The rats were then removed from the open field and returned to their cages. The surface was cleaned with $70 \%$ ethanol before each test. Ambulatory locomotor activity was measured by the total number of squares entered by the rats (Figs. $2 \mathrm{~d}$ and $3 \mathrm{c}$ ) [47].

\section{Statistical Analysis}

Statistical analysis was performed using SPSS v25. All data are presented as mean \pm standard error of the mean. For continuous variables, one-way repeated measure analysis of variance (ANOVA) (followed by Tukey's post hoc test) was used for multiple comparisons and two-tailed Student's $t$ test for two-group comparisons. For categorical variables, Pearson chi-square test was used. Differences between the experimental groups were considered statistically significant at $p<0.05$.

\section{Results}

All animals included in the present study were subjected to an 8-day period of habituation (Fig. 1a) before assessing their locomotor response to an incremental load test of forced wheel running $[42,43]$. Typically, the locomotor performance is revealed by the amount of time spent running while the rotation speed of the wheel increases (Fig. 1b). Relative to the vehicle group, systemic (i.p.) administration of $\mathrm{SCH} 23390(0.1$ and $0.2 \mathrm{mg} / \mathrm{kg})$ or raclopride $(0.5$ and $1 \mathrm{mg} / \mathrm{kg}$ ) alone reduced the time of running during the incremental test in a dose-dependent manner (Fig. 2a, b). Interestingly, the behavioral effects of SCH23390 and raclopride alone are comparable. Next, the administration of the lowest effective dose of SCH23390 $(0.1 \mathrm{mg} / \mathrm{kg})+$ raclopride $(0.5 \mathrm{mg} / \mathrm{kg})$ given together showed a marked locomotor disruption during the incremental test (Fig. 2c). Despite that the overall level of locomotor disruption observed with SCH23390 or raclopride alone is not statistically different from SCH23390 + raclopride ( $p=0.053$ vs SCH23390 or raclopride alone, one-way ANOVA), none of the animals from the latter group surpassed the 5-min running time $(p<0.0001$ vs raclopride alone, $p<0.005$ vs $\mathrm{SCH} 23390$ alone, chi-square test) (Fig. 2c). These data indicate that activation of D1 and D2 receptors are required to sustain the locomotor response to incremental loads of forced running. However, our data also revealed that systemic blockade of either D1 or D2 receptors independently is sufficient to disrupt the locomotor behavior in the open field, although a robust motor impairment emerges following systemic administration of SCH23390 + raclopride (Fig. 2d). Together, these results imply that both motor skills in the running wheel and locomotor activity in the open field are dopamine dependent.

We next asked whether the comparable locomotor disruption resulting from systemic administration of SCH23390 and raclopride when given alone shares a common anatomical target. Of particular interest is the striatum, one of the major targets of dopamine and well-known for its role in modulating motor behavior [19-23, 48, 49]. Thus, it is possible that the behavioral effects observed following systemic administration of dopamine antagonists occurred through the striatum. To test this hypothesis, we generated another cohort of rats where guide cannulas were placed into the dorsal striatum (Fig. 3a) and changes in the duration of forced running during the incremental test were assessed following striatal injections of SCH23390 or raclopride (Fig. 3b). Relative to vehicle infusions, striatal delivery of SCH23390 $(10-100 \mu \mathrm{M})$ reduced the time spent during the incremental test (Fig. 3b). Interestingly, this was not the case following infusions of raclopride $(20 \mu \mathrm{M}-5 \mathrm{mM})$ as revealed by the level of locomotor performance resembling that of the vehicle group (Fig. 3b). Of note, striatal injections of SCH23390 did not disrupt locomotor activity in the open field (Fig. 3c), which implies that striatal D1 receptor signaling is preferentially recruited during incremental loads of forced running. Furthermore, the lack of effect after intrastriatal administration of raclopride together with the observed systemic effect implies an extra-striatal D2 
receptor signaling mechanism underlying the modulation of the behavioral response during the incremental test.

\section{Discussion}

In the present study, we found that the level of locomotor response to incremental loads of forced running in adolescent rats is dopamine dependent and mechanistically linked to the activation of D1 and D2 receptors. Our data also show that striatal blockade of D1, but not D2 receptors, reduced the response during the incremental test. Together, these results imply a recruitment of striatal and extra-striatal D1 and D2 receptor signaling to sustain proper level of locomotor performance during forced running.

The dopaminergic system is known to play a key role in the development and maturation of neural circuits associated with cognitive and motor learning behaviors during adolescence $[3$, 15, 19-23, 41]. Accordingly, systemic administration of D1 and $\mathrm{D} 2$ receptor antagonists reduced the duration of forced running in a dose-dependent manner. Of note, both dopamine receptor antagonists elicited similar levels of locomotor disruptions when given alone, which is consistent with the idea of a synergistic D1-D2 action to maintain coordinated motor activity [50-53]. However, the behavioral impact of D1 and D2 receptor antagonists was not limited to reducing the response in the forced running wheel, as revealed by the attenuated locomotor activity in the open field and severe motor deficit when SCH23390 + raclopride were administered together. In fact, dopamine antagonists also impair motor coordination during voluntary wheel running $[20,32,34,54]$. This suggests a common neural mechanism underlying the regulation of ambulatory locomotor activity and motor skills in the running wheel by dopamine. Future studies are warranted to determine whether the neural substrate modulating the motor response is age dependent, despite the fact that the results obtained in the open field from adolescent rats are similar to those induced by $\mathrm{SCH} 23390[33,53,55,56]$ and raclopride $[30,31,56,57]$ in adults.

The striatum is the main input structure of the basal ganglia circuitry involved in motor control and one of the brain regions with the highest expression of dopamine receptors [15, 19-23, 44, 48, 49, 58]. Thus, the level of locomotor response to incremental loads of forced running is expected to be mitigated following striatal delivery of dopamine receptor antagonists. Our data revealed that only striatal D1 receptors are required to maintain proper levels of performance during forced running, whereas striatal D2 receptors are not. These findings are consistent with the prominent role of striatal D1 receptors over D2 receptors in the regulation of coordinated motor behavior [20, 59-64], including voluntary wheel running [20] and ambulatory activity $[49,65]$. However, our results also suggest that there is an extra-striatal component modulated by D2 receptors that acts synergistically with the striatal D1 receptor signaling to sustain the behavioral response during incremental loads of forced running.

In our previous $[42,43]$ and current studies, the exposure to an 8-day period of habituation is critical to enable a higher locomotor performance in the forced running wheel $[42,43]$. It is therefore conceivable that the dopaminergic system is also recruited during the habituation phase to enhance the level of motor coordination and response to incremental loads of running. While such a dopaminergic effect could be mediated by several cellular and synaptic mechanisms, activation of striatal D1 receptors can effectively potentiate corticostriatal transmission $[62,66-71]$ during habituation to promote motor coordination and motor skill learning [20, 59-61]. Remarkably, our data also point toward the contribution of extrastriatal D2 receptors [72-78] in facilitating the behavioral response, despite the fact that D1 and D2 receptors often exert opposing postsynaptic effects [24-26]. Certainly, D2 receptor deletion impairs locomotion, motor skill learning, and coordination [79-81], resembling the motor disruption elicited by chronic depletion of the nigrostriatal dopamine pathway and associated striatal deficit of D2 receptor signaling $[79,82-86]$. Hence, it is possible that striatal and extra-striatal motor circuits are gradually recruited by D2 receptors during the habituation period [3, 72-78] to enable the potentiation of corticostriatal transmission and locomotor response by D1 receptors.

In addition to the dorsal striatum and dopamine, other motor-related neurotransmitter systems, such as serotonin [87], and extra-striatal structures are likely to interact in the regulation of exercise capacity. In this regard, the nucleus accumbens has been pointed as a critical component in modulating effort-related functions due to its role in decisionmaking and motivation $[72,88,89]$. Other candidate structures include the globus pallidus, since it has been highlighted to orchestrate dynamic aspects of basal ganglia regulation of motor coordination [90]. Although the integration of sensory and cognitive information by the striatum is required during movement initiation [58], increments in striatal activity are often preceded by convergent projections from multiple cortical areas, such as the motor cortex [76] and the prefrontal cortex. The latter cortical region is of particular interest for its importance in the neural maturation during adolescence [13, 14] as well as its role in working memory, planning, and executive functions [91].

Collectively, the results presented here indicate that coordinated modulation of striatal and extra-striatal neural circuits' activity by dopamine could play a major role in adjusting the level of locomotor response during forced running. Whether similar neural mechanisms are recruited to enhance other forms of effort-related motor skill behaviors $[3,72,89]$ remains to be determined. 
Authors' Contributions Conceptualization: AT, KYT, and JLF. Methodology: AT, DG, YK, MP, BRC, NMD, KYT, and JLF. Validation: AT, DG, KYT, and JLF. Formal analysis: AT, DG, MP, KYT, and JLF. Investigation: AT, DG, YK, and JLF. Resources: KYT and JLF. Writing - original draft: AT, KYT, and JLF. Writing - review and editing: AT, DG, YK, MP, BRC, NMD, KYT, and JLF. Supervision: KYT and JLF, Funding acquisition: JLF. Project administration: JLF.

Funding Granted by the Spanish Ministry of Science, Innovation and Universities and European Regional Development Fund (FEDER; PGC2018-098229-B-100 to JLF) and by Séneca Foundation (19904/ GERM/15).

Data Availability The dataset generated during the current study are available from the corresponding author on reasonable request.

\section{Compliance with Ethical Standards}

Conflict of Interest The authors declare that they have no conflict of interest.

Ethics Approval All the experimental procedures were approved by the Ethical Committee for Animal Research (CEEA) of the University of Murcia according to Spanish regulation for the use of animals for scientific purposes (Royal Degree 53/2013, Law 32/2007) and European Union directives (86/609/EEC).

\section{Consent to Participate None.}

\section{Consent for Publication None.}

\section{Code Availability None.}

Open Access This article is licensed under a Creative Commons Attribution 4.0 International License, which permits use, sharing, adaptation, distribution and reproduction in any medium or format, as long as you give appropriate credit to the original author(s) and the source, provide a link to the Creative Commons licence, and indicate if changes were made. The images or other third party material in this article are included in the article's Creative Commons licence, unless indicated otherwise in a credit line to the material. If material is not included in the article's Creative Commons licence and your intended use is not permitted by statutory regulation or exceeds the permitted use, you will need to obtain permission directly from the copyright holder. To view a copy of this licence, visit http://creativecommons.org/licenses/by/4.0/.

\section{References}

1. Ruegsegger GN, Booth FW (2017) Health benefits of exercise. Cold Spring Harb Perspect Med 8(7):a029694. https://doi.org/10. 1101/cshperspect.a029694

2. WHO (2018) Global action plan on physical activity 2018-2030: more active people for a healthier world. World Health Organization, Geneva

3. Foley TE, Fleshner M (2008) Neuroplasticity of dopamine circuits after exercise: implications for central fatigue. NeuroMolecular Med 10(2):67-80. https://doi.org/10.1007/s12017-008-8032-3

4. Erickson KI, Miller DL, Weinstein AM, Akl SL, Banducci S (2012) Physical activity and brain plasticity in late adulthood: a conceptual and comprehensive review. Ageing Research 3(1):e6. https://doi. org/10.4081/ar.2012.e6

5. Dayan E, Cohen LG (2011) Neuroplasticity subserving motor skill learning. Neuron 72(3):443-454. https://doi.org/10.1016/j.neuron. 2011.10.008

6. Dishman RK, Berthoud HR, Booth FW, Cotman CW, Edgerton VR, Fleshner MR, Gandevia SC, Gomez-Pinilla F et al (2006) Neurobiology of exercise. Obesity 14(3):345-356. https://doi.org/ 10.1038/oby.2006.46

7. Goldstein RE (1990) Exercise capacity. In: Walker HK, Hall WD, Hurst JW (eds) Clinical Methods: the history, physical, and laboratory examinations, 3rd edn. Butterworths, Boston

8. American College of Sport Medicine (2018) ACSM's guidelines for exercise testing and prescription, Tenth edn. Wolters Kluwer Health, Philadelphia

9. Bedford TG, Tipton CM, Wilson NC, Oppliger RA, Gisolfi CV (1979) Maximum oxygen consumption of rats and its changes with various experimental procedures. J Appl Physiol 47(6):1278-1283. https://doi.org/10.1152/jappl.1979.47.6.1278

10. Myers J, Prakash M, Froelicher V, Do D, Partington S, Atwood JE (2002) Exercise capacity and mortality among men referred for exercise testing. N Engl J Med 346(11):793-801. https://doi.org/ 10.1056/NEJMoa011858

11. Bergeron MF, Mountjoy M, Armstrong N, Chia M, Côté J, Emery CA, Faigenbaum A, Hall G et al (2015) International Olympic Committee consensus statement on youth athletic development. Br J Sports Med 49(13):843-851. https://doi.org/10.1136/ bjsports-2015-094962

12. Lloyd RS, Oliver JL, Faigenbaum AD, Howard R, Croix MBDS, Williams CA, Best TM, Alvar BA et al (2015) Long-term athletic development-part 1: a pathway for all youth. The Journal of Strength \& Conditioning Research 29(5):1439-1450. https://doi. org/10.1519/JSC.0000000000000756

13. Caballero A, Granberg R, Tseng KY (2016) Mechanisms contributing to prefrontal cortex maturation during adolescence. Neurosci Biobehav Rev 70:4-12. https://doi.org/10.1016/j.neubiorev.2016. 05.013

14. Caballero A, Tseng KY (2016) GABAergic function as a limiting factor for prefrontal maturation during adolescence. Trends Neurosci 39(7):441-448. https://doi.org/10.1016/j.tins.2016.04. 010

15. Spear LP (2000) The adolescent brain and age-related behavioral manifestations. Neurosci Biobehav Rev 24(4):417-463. https://doi. org/10.1016/s0149-7634(00)00014-2

16. Hopkins ME, Nitecki R, Bucci DJ (2011) Physical exercise during adolescence versus adulthood: differential effects on object recognition memory and brain-derived neurotrophic factor levels. Neuroscience 194:84-94. https://doi.org/10.1016/j.neuroscience. 2011.07.071

17. Belcher BR, Zink J, Azad A, Campbell CE, Chakravartti SP, Herting MM (2020) The roles of physical activity, exercise, and fitness in promoting resilience during adolescence: effects on mental well-being and brain development. Biological Psychiatry: Cognitive Neuroscience and Neuroimaging. https://doi.org/10. 1016/j.bpsc.2020.08.005

18. Dwyer JB, Leslie FM (2016) Adolescent maturation of dopamine D1 and D2 receptor function and interactions in rodents. PLoS One 11(1):e0146966. https://doi.org/10.1371/journal.pone.0146966

19. Wickens JR, Reynolds JN, Hyland BI (2003) Neural mechanisms of reward-related motor learning. Curr Opin Neurobiol 13(6):685690. https://doi.org/10.1016/j.conb.2003.10.013

20. Willuhn I, Steiner H (2008) Motor-skill learning in a novel runningwheel task is dependent on D1 dopamine receptors in the striatum. Neuroscience 153(1):249-258. https://doi.org/10.1016/j. neuroscience.2008.01.041 
21. Crisp KM, Gallagher BR, Mesce KA (2012) Mechanisms contributing to the dopamine induction of crawl-like bursting in leech motoneurons. J Exp Biol 215(17):3028-3036. https://doi.org/10. 1242/jeb.069245

22. Steiner H, Tseng KY (2016) Handbook of basal ganglia structure and function. Academic Press, Elsevier

23. Tritsch NX, Sabatini BL (2012) Dopaminergic modulation of synaptic transmission in cortex and striatum. Neuron 76(1):33-50. https://doi.org/10.1016/j.neuron.2012.09.023

24. Schwartz J-C, Giros B, Martres M-P, Sokoloff P (1992) The dopamine receptor family: molecular biology and pharmacology. In: Seminars in Neuroscience, vol 2. Elsevier, pp. 99-108. https://doi. org/10.1016/1044-5765(92)90008-P

25. Kumar U, Patel SC (2007) Immunohistochemical localization of dopamine receptor subtypes (D1R-D5R) in Alzheimer's disease brain. Brain Res 1131:187-196. https://doi.org/10.1016/j.brainres. 2006.10.049

26. Beaulieu J-M, Gainetdinov RR (2011) The physiology, signaling, and pharmacology of dopamine receptors. Pharmacol Rev 63(1): 182-217. https://doi.org/10.1124/pr.110.002642

27. Presti MF, Mikes HM, Lewis MH (2003) Selective blockade of spontaneous motor stereotypy via intrastriatal pharmacological manipulation. Pharmacol Biochem Behav 74(4):833-839. https://doi. org/10.1016/S0091-3057(02)01081-X

28. Meyer ME (1993) Effects of intraaccumbens dopamine agonist SKF38393 and antagonist SCH23390 on locomotor activities in rats. Pharmacol Biochem Behav 45(4):843-847. https://doi.org/ 10.1016/0091-3057(93)90130-1

29. Horvitz JC, Williams G, Joy R (2001) Time-dependent actions of D 2 family agonist quinpirole on spontaneous behavior in the rat: dissociation between sniffing and locomotion. Psychopharmacology 154(4):350-355. https://doi.org/10.1007/ s002130000677

30. Simon V, Parra A, Minarro J, Arenas M, Vinader-Caerols C, Aguilar M (2000) Predicting how equipotent doses of chlorpromazine, haloperidol, sulpiride, raclopride and clozapine reduce locomotor activity in mice. Eur Neuropsychopharmacol 10(3):159 164. https://doi.org/10.1016/S0924-977X(00)00070-5

31. Hillegaart V, Ahlenius S (1987) Effects of raclopride on exploratory locomotor activity, treadmill locomotion, conditioned avoidance behaviour and catalepsy in rats: behavioural profile comparisons between raclopride, haloperidol and preclamol. Basic Clin Pharmacol Toxicol 60(5):350-354. https://doi.org/10.1111/j.16000773.1987.tb01525.x

32. Rhodes J, Garland T (2003) Differential sensitivity to acute administration of Ritalin, apormorphine, $\mathrm{SCH} 23390$, but not raclopride in mice selectively bred for hyperactive wheel-running behavior. Psychopharmacology 167(3):242-250. https://doi.org/10.1007/ s00213-003-1399-9

33. Hoffman DC, Beninger RJ (1985) The D1 dopamine receptor antagonist, $\mathrm{SCH} 23390$ reduces locomotor activity and rearing in rats. Pharmacol Biochem Behav 22(2):341-342. https://doi.org/10. 1016/0091-3057(85)90401-0

34. Knab A, Bowen R, Hamilton A, Lightfoot J (2012) Pharmacological manipulation of the dopaminergic system affects wheel-running activity in differentially active mice. J Biol Regul Homeost Agents 26(1):119. https://doi.org/10.14254/2071-8330. 2014/7-3/12

35. Fisher BE, Petzinger GM, Nixon K, Hogg E, Bremmer S, Meshul CK, Jakowec MW (2004) Exercise-induced behavioral recovery and neuroplasticity in the 1-methyl-4-phenyl-1, 2, 3, 6tetrahydropyridine-lesioned mouse basal ganglia. J Neurosci Res 77(3):378-390. https://doi.org/10.1002/jnr.20162

36. Petzinger GM, Walsh JP, Akopian G, Hogg E, Abernathy A, Arevalo P, Turnquist P, Vučković M et al (2007) Effects of treadmill exercise on dopaminergic transmission in the 1-methyl-4- phenyl-1, 2, 3, 6-tetrahydropyridine-lesioned mouse model of basal ganglia injury. J Neurosci 27(20):5291-5300. https://doi.org/10. 1523/JNEUROSCI.1069-07.2007

37. Petzinger GM, Holschneider D, Fisher B, McEwen S, Kintz N, Halliday M, Toy W, Walsh J et al (2015) The effects of exercise on dopamine neurotransmission in Parkinson's disease: targeting neuroplasticity to modulate basal ganglia circuitry. Brain plasticity 1(1):29-39. https://doi.org/10.3233/bpl-150021

38. Beeler JA, Cao ZFH, Kheirbek MA, Ding Y, Koranda J, Murakami M, Kang UJ, Zhuang X (2010) Dopamine-dependent motor learning: insight into levodopa's long-duration response. Ann Neurol 67(5):639-647. https://doi.org/10.1002/ana.21947

39. Rabelo P, Almeida T, Guimaraes J, Barcellos L, Cordeiro L, Moraes M, Coimbra C, Szawka R et al (2015) Intrinsic exercise capacity is related to differential monoaminergic activity in the rat forebrain. Brain Res Bull 112:7-13. https://doi.org/10.1016/j. brainresbull.2015.01.006

40. Cordeiro L, Rabelo P, Moraes M, Teixeira-Coelho F, Coimbra C, Wanner SP, Soares DD (2017) Physical exercise-induced fatigue: the role of serotonergic and dopaminergic systems. Braz J Med Biol Res 50(12):e6432. https://doi.org/10.1590/1414-431X20176432

41. Balthazar CH, Leite LH, Ribeiro RM, Soares DD, Coimbra CC (2010) Effects of blockade of central dopamine D1 and D 2 receptors on thermoregulation, metabolic rate and running performance. Pharmacol Rep 62(1):54-61. https://doi.org/10.1016/s17341140(10)70242-5

42. Toval A, Baños R, De la Cruz E, Morales-Delgado N, Pallares JG, Ayad A, Tseng KY, Ferran JL (2017) Habituation training improves locomotor performance in a forced running wheel system in rats. Front Behav Neurosci 11:42. https://doi.org/10.3389/fnbeh. 2017.00042

43. Toval A, Vicente-Conesa F, Martínez-Ortega P, Kutsenko Y, Morales-Delgado N, Garrigos D, Alonso A, Do Couto BR et al (2020) Hypothalamic Crh/Avp, plasmatic glucose and lactate remain unchanged during habituation to forced exercise. Front Physiol 11. https://doi.org/10.3389/fphys.2020.00410

44. Gerfen CR, Surmeier DJ (2011) Modulation of striatal projection systems by dopamine. Annu Rev Neurosci 34:441-466. https://doi. org/10.1146/annurev-neuro-061010-113641

45. Jayasinghe VR, Flores-Barrera E, West AR, Tseng KY (2017) Frequency-dependent corticostriatal disinhibition resulting from chronic dopamine depletion: role of local striatal cGMP and GABA-AR signaling. Cereb Cortex 27(1):625-634. https://doi. org/10.1093/cercor/bhv241

46. Paxinos G, Watson C (2007) The rat brain in stereotaxic coordinates, 6th edn. Elsevier

47. Popović N, Giménez de Béjar V, Caballero-Bleda M, Popović M (2017) Verapamil parameter-and dose-dependently impairs memory consolidation in open field habituation task in rats. Front Pharmacol 7:539. https://doi.org/10.3389/fphar.2016.00539

48. Kreitzer AC, Malenka RC (2008) Striatal plasticity and basal ganglia circuit function. Neuron 60(4):543-554. https://doi.org/10. 1016/j.neuron.2008.11.005

49. Shapovalova K, Kamkina YV (2008) Motor and cognitive functions of the neostriatum during bilateral blockade of its dopamine receptors. Neurosci Behav Physiol 38(1):71-79. https://doi.org/10. 1007/s11055-008-0010-6

50. Pandey P, Mersha MD, Dhillon HS (2013) A synergistic approach towards understanding the functional significance of dopamine receptor interactions. J Mol Signal 8(1):13. https://doi.org/10.1186/ 1750-2187-8-13

51. Waszczak BL, Martin LP, Finlay HE, Zahr N, Stellar JR (2002) Effects of individual and concurrent stimulation of striatal D1 and D2 dopamine receptors on electrophysiological and behavioral output from rat basal ganglia. J Pharmacol Exp Ther 300(3):850-861. https://doi.org/10.1124/jpet.300.3.850 
52. Nolan EB, Harrison LM, Lahoste GJ, Ruskin DN (2007) Behavioral synergism between D1 and D2 dopamine receptors in mice does not depend on gap junctions. Synapse 61(5):279-287. https://doi.org/10.1002/syn.20371

53. Bourne JA (2001) SCH 23390: the first selective dopamine D1-like receptor antagonist. CNS drug reviews 7(4):399-414. https://doi. org/10.1111/j.1527-3458.2001.tb00207.x

54. Rhodes JS, Gammie SC, Garland T Jr (2005) Neurobiology of mice selected for high voluntary wheel-running activity. Integr Comp Biol 45(3):438-455. https://doi.org/10.1093/icb/45.3.438

55. Christensen A, Arnt J, Hyttel J, Larsen J-J, Svendsen O (1984) Pharmacological effects of a specific dopamine D-1 antagonist SCH 23390 in comparison with neuroleptics. Life Sci 34(16): 1529-1540. https://doi.org/10.1016/0024-3205(84)90607-6

56. Ågmo A, Soria P (1999) The duration of the effects of a single administration of dopamine antagonists on ambulatory activity and motor coordination. J Neural Transm 106(3-4):219-227. https://doi.org/10.1007/s007020050152

57. Protais P, Chagraoui A, Arbaoui J, Mocaër E (1994) Dopamine receptor antagonist properties of S 14506, 8-OH-DPAT, raclopride and clozapine in rodents. Eur J Pharmacol 271(1):167-177. https:// doi.org/10.1016/0014-2999(94)90277-1

58. Klaus A, Alves da Silva J, Costa RM (2019) What, if, and when to move: basal ganglia circuits and self-paced action initiation. Annu Rev Neurosci 42:459-483. https://doi.org/10.1146/annurev-neuro072116-031033

59. Beninger RJ, Miller R (1998) Dopamine D1-like receptors and reward-related incentive learning. Neurosci Biobehav Rev 22(2): 335-345. https://doi.org/10.1016/S0149-7634(97)00019-5

60. Kabai P, Stewart MG, Tarcali J, Csillag A (2004) Inhibiting effect of D1, but not D2 antagonist administered to the striatum on retention of passive avoidance in the chick. Neurobiol Learn Mem 81(2): 155-158. https://doi.org/10.1016/j.nlm.2003.12.002

61. Domenger D, Schwarting RK (2006) The serial reaction time task in the rat: effects of D1 and D2 dopamine-receptor antagonists. Behav Brain Res 175(2):212-222. https://doi.org/10.1016/j.bbr. 2006.08.027

62. Liste I, Guerra M, Caruncho H, Labandeira-Garcia J (1997) Treadmill running induces striatal Fos expression via NMDA glutamate and dopamine receptors. Exp Brain Res 115(3):458-469. https://doi.org/10.1007/p100005715

63. Nakamura T, Rios LC, Yagi T, Sasaoka T, Kitsukawa T (2019) Dopamine D1 and muscarinic acetylcholine receptors in dorsal striatum are required for high speed running. Neurosci Res 156:50-57. https://doi.org/10.1016/j.neures.2019.12.001

64. Avila-Luna A, Gálvez-Rosas A, Durand-Rivera A, RamosLanguren L-E, Ríos C, Arias-Montaño J-A, Bueno-Nava A (2018) Dopamine D 1 receptor activation maintains motor coordination and balance in rats. Metab Brain Dis 33(1):99-105. https:// doi.org/10.1007/s11011-017-0126-x

65. Steiner H, Kitai ST (2000) Regulation of rat cortex function by D1 dopamine receptors in the striatum. J Neurosci 20(14):5449-5460. https://doi.org/10.1523/JNEUROSCI.20-14-05449.2000

66. Centonze D, Grande C, Saulle E, Martín AB, Gubellini P, Pavón N, Pisani A, Bernardi G et al (2003) Distinct roles of D1 and D5 dopamine receptors in motor activity and striatal synaptic plasticity. J Neurosci 23(24):8506-8512. https://doi.org/10.1523/ JNEUROSCI.23-24-08506.2003

67. Huang Y-Y, Simpson E, Kellendonk C, Kandel ER (2004) Genetic evidence for the bidirectional modulation of synaptic plasticity in the prefrontal cortex by D1 receptors. Proc Natl Acad Sci 101(9): 3236-3241. https://doi.org/10.1073/pnas.0308280101

68. Calabresi P, Gubellini P, Centonze D, Picconi B, Bernardi G, Chergui K, Svenningsson P, Fienberg AA et al (2000) Dopamine and cAMP-regulated phosphoprotein $32 \mathrm{kDa}$ controls both striatal long-term depression and long-term potentiation, opposing forms of synaptic plasticity. J Neurosci 20(22):8443-8451. https://doi. org/10.1523/JNEUROSCI.20-22-08443.2000

69. Tseng KY, Snyder-Keller A, O’Donnell P (2007) Dopaminergic modulation of striatal plateau depolarizations in corticostriatal organotypic cocultures. Psychopharmacology 191(3):627-640. https://doi.org/10.1007/s00213-006-0439-7 Free PMC article

70. Oswald MJ, Schulz JM, Kelsch W, Oorschot DE, Reynolds JN (2015) Potentiation of NMDA receptor-mediated transmission in striatal cholinergic interneurons. Front Cell Neurosci 9:116. https://doi.org/10.3389/fncel.2015.00116

71. Villar FDS, Walsh J (1999) Modulation of long-term synaptic plasticity at excitatory striatal synapses. Neuroscience 90(3):10311041. https://doi.org/10.1016/s0306-4522(98)00504-1

72. Farrar AM, Segovia KN, Randall PA, Nunes EJ, Collins LE, Stopper CM, Port RG, Hockemeyer J et al (2010) Nucleus accumbens and effort-related functions: behavioral and neural markers of the interactions between adenosine A2A and dopamine D2 receptors. Neuroscience 166(4):1056-1067. https://doi.org/10.1016/j. neuroscience.2009.12.056

73. Tseng KY, O'Donnell P (2007) D2 dopamine receptors recruit a GABA component for their attenuation of excitatory synaptic transmission in the adult rat prefrontal cortex. Synapse 61(10):843-850. https://doi.org/10.1002/syn.20432

74. Santana N, Mengod G, Artigas F (2009) Quantitative analysis of the expression of dopamine D1 and D2 receptors in pyramidal and GABAergic neurons of the rat prefrontal cortex. Cereb Cortex 19(4):849-860. https://doi.org/10.1093/cercor/bhn134

75. Del Arco A, Mora F, Mohammed A, Fuxe K (2007) Stimulation of $\mathrm{D} 2$ receptors in the prefrontal cortex reduces $\mathrm{PCP}$-induced hyperactivity, acetylcholine release and dopamine metabolism in the nucleus accumbens. J Neural Transm 114(2):185-193. https://doi.org/ 10.1007/s00702-006-0533-3

76. Molina-Luna K, Pekanovic A, Röhrich S, Hertler B, SchubringGiese M, Rioult-Pedotti M-S, Luft AR (2009) Dopamine in motor cortex is necessary for skill learning and synaptic plasticity. PLoS One 4(9):e7082. https://doi.org/10.1371/journal.pone.0007082

77. Hosp J, Molina-Luna K, Hertler B, Atiemo CO, Luft A (2009) Dopaminergic modulation of motor maps in rat motor cortex: an in vivo study. Neuroscience 159(2):692-700. https://doi.org/10. 1016/j.neuroscience.2008.12.056

78. Vitrac C, Péron S, Frappé I, Fernagut P-O, Jaber M, Gaillard A, Benoit-Marand M (2014) Dopamine control of pyramidal neuron activity in the primary motor cortex via D2 receptors. Frontiers in Neural Circuits 8:13. https://doi.org/10.3389/fncir.2014.00013

79. Bello E, Casas-Cordero R, Galiñanes GL, Casey E, Belluscio MA, Rodríguez V, Noaín D, Murer MG et al (2017) Inducible ablation of dopamine D2 receptors in adult mice impairs locomotion, motor skill learning and leads to severe parkinsonism. Mol Psychiatry 22(4):595-604. https://doi.org/10.1038/mp.2016.105

80. Clifford JJ, Kinsella A, Tighe O, Rubinstein M, Grandy DK, Low MJ, Croke DT, Waddington JL (2001) Comparative, topographically-based evaluation of behavioural phenotype and specification of D1-like: D2 interactions in a line of incipient congenic mice with D2 dopamine receptor 'knockout'. Neuropsychopharmacology 25(4):527-536. https://doi.org/10. 1016/S0893-133X(01)00246-9

81. Kelly MA, Rubinstein M, Phillips TJ, Lessov CN, Burkhart-Kasch S, Zhang G, Bunzow JR, Fang Y et al (1998) Locomotor activity in D2 dopamine receptor-deficient mice is determined by gene dosage, genetic background, and developmental adaptations. J Neurosci 18(9):3470-3479. https://doi.org/10.1523/JNEUROSCI. 18-09-03470.1998

82. Zhang J, Goodlett DR (2004) Proteomic approach to studying Parkinson's disease. Mol Neurobiol 29(3):271-288. https://doi. org/10.1385/MN:29:3:271 
83. Smith AD, Zigmond MJ (2003) Can the brain be protected through exercise? Lessons from an animal model of parkinsonism. Exp Neurol 184(1):31-39. https://doi.org/10.1016/j.expneurol.2003.08. 017

84. Dagher A, Robbins TW (2009) Personality, addiction, dopamine: insights from Parkinson's disease. Neuron 61(4):502-510. https:// doi.org/10.1016/j.neuron.2009.01.031

85. Aoyama S, Kase H, Borrelli E (2000) Rescue of locomotor impairment in dopamine D2 receptor-deficient mice by an adenosine A2A receptor antagonist. J Neurosci 20(15):5848-5852. https://doi.org/ 10.1523/JNEUROSCI.20-15-05848.2000

86. Baik J-H, Picetti R, Saiardi A, Thiriet G, Dierich A, Depaulis A, Le Meur M, Borrelli E (1995) Parkinsonian-like locomotor impairment in mice lacking dopamine D2 receptors. Nature 377(6548):424 428. https://doi.org/10.1038/377424a0

87. Meeusen R, Watson P, Hasegawa H, Roelands B, Piacentini MF (2007) Brain neurotransmitters in fatigue and overtraining. Appl Physiol Nutr Metab 32(5):857-864
88. Salamone JD, Correa M (2012) The mysterious motivational functions of mesolimbic dopamine. Neuron 76(3):470-485

89. Salamone JD, Correa M, Ferrigno S, Yang J-H, Rotolo RA, Presby RE (2018) The psychopharmacology of effort-related decision making: dopamine, adenosine, and insights into the neurochemistry of motivation. Pharmacol Rev 70(4):747-762. https://doi.org/10. 1124/pr.117.015107

90. de la Crompe B, Aristieta A, Leblois A, Elsherbiny S, Boraud T, Mallet NP (2020) The globus pallidus orchestrates abnormal network dynamics in a model of parkinsonism. Nat Commun 11(1):114. https://doi.org/10.1038/s41467-020-15352-3

91. Fuster JM (2001) The prefrontal cortex - an update: time is of the essence. Neuron 30(2):319-333

Publisher's Note Springer Nature remains neutral with regard to jurisdictional claims in published maps and institutional affiliations. 